\title{
WORK CONDITIONS AND HEALTH RISKS OF PERSONS EMPLOYED IN CONSTRUCTION IN LATVIA
}

\author{
Tatjana Farbtuha, Žanna Martinsone, Ivars Vanadziṇš, Jānis Dundurs, Inese Mārtiṇsone, \\ and Anita Pikie
}

Institute of Occupational Safety and Environmental Health, Rīga Stradiṇš University, Dzirciema iela 16, Rīga, LV-1007, LATVIA

E-mail: Zanna.Martinsone@ @rsu.lv

Communicated by Rafails Rozentāls

\begin{abstract}
The health effects of the work condition in construction were the focus for this study. The construction sector involves numerous risk factors, which can essentially endanger employee health and safety by causing accidents, occupational diseases and work-related diseases. The aim of this study was to examine the work condition, identity risk factors in the workplace, analyse the morbidity and accidents in the construction sector. According to the data of the State Revenue Service, the number of persons employed in construction in Latvia is growing each year. In the construction sector the number of accidents per 100000 employees has tended to fall between 2003 and 2005, but the number of serious accidents has risen 1.3 times. Employees in construction companies are not sufficiently informed about the work environment risk factors and their influence on health and safety.
\end{abstract}

Key words: construction, employer, employee, working environment, risk factors, occupational safety, accident, occupational diseases, regulation.

\section{INTRODUCTION}

Construction covers a very broad scope of work, which is associated with the presence simultaneously of different risk factors in the work environment (Roja and Kalkis, 2001). Construction is characterised by an extremely wide range of tasks to be performed by incorporating many types of work, frequent change of the combination of risk factors, and combined effect (Latze et al., 2000; Thevendrom and Mawdeslay, 2004).

The construction sector involves numerous risk factors, which can essentially endanger employee health and safety, by causing accidents, occupational diseases and workrelated diseases (Roja and Kal,kis, 2001). The following factors are among the most important work environment risk factors that affect or might affect the health of the employed in construction:

- work at height, in closed premises;

- risk factors causing traumatism;

- the work with dangerous equipment (lifts, cranes, hoists, pulleys, lifts), power equipment and pressure equipment (for example, compressed gas cylinders in welding works) (Grausenth et al., 2006; Gürcanli et al., 2008).

- physical factors (noise, vibration, illumination, microclimate (including effect of atmospheric conditions, increased atmospheric pressure, for example, in caissons);
- ergonomic factors - hard work, repetitive physical strain, work postures (for example, handling of construction materials) (Latze et al., 2000);

- chemical substances, which can emerge in the construction process, by use of, for example, cement dust, lacquers, paints, solvents, welding aerosol, hydro- and thermal insulating materials, causing exposure to concreter workers, painters, welders, finishing product workers);

- ultraviolet and infrared radiation (for welders);

- mental overload (long working hours, shift work, several works, etc.).

According to State Labour Inspectorate data, the number of accidents at work in construction (NACE code F45) in the last four years is on average 214.5 per 100000 employees including 67 workers per 100000 employees who sustained serious injuries, and 15.9 cases per 100000 employees who suffered fatal accidents. Traumatism can be caused by lifting, transporting materials, work with equipment and dangerous equipment, as well as electricity traumas. Dangerous equipment is connected with an increased number of accidents, resulting in the loss of work time as well as very serious, often fatal health disorders. Manual tools cause numerous accidents at work; however, these are mostly light accidents without a fatal result (Roja and Kal,kis, 2001; Anonīms, 2003; Gürcanli et al., 2008). 
Construction is associated with both continuous and impulse noise, for example, pile driving when building foundations. The increased noise level in the work environment can not only deteriorate hearing, but also cause non-specific changes in organ systems, for instance, the central nervous system and cardiovascular system. When the work environment is noisy, the worker has difficulty in communicating with his fellow workers, thus, it is nearly impossible to warn of danger, which results also in increased accident risk (Thevendrom and Mawdeslay, 2004).

Equipment and instruments used in construction can cause local or whole body vibration. Vibration can have a negative impact on the worker (Seidel, 2008; Sauni et al., 2010).

Those employed in construction encounter a high contact risk with chemical substances, particularly in the form of different dust aerosols, both when building new houses, or demolishing old ones, when carrying out grinding, polishing and repair works, and also in earth works when building foundations. These are mainly free silicon dioxide or silicate (for instance, cement, mica, asbestos) dust, metal oxides containing dust in welding aerosol, abrasive dust, wood and polymers containing dust. The dust aerosols affect mostly the respiratory apparatus. First, the mucous membrane of upper respiratory tract is affected causing pathologic changes. At the start of exposure, dust can cause acute inflammation, which later develops into a chronic form; if exposure to dust is continued, chronic atrophic inflammation of the upper respiratory tract develops. When dust is being accumulated in lungs causing reaction by tissues, the pneumoconiosis is not uncommon (Eglite, 2000).

In construction, during mechanic processing works, particularly welding, workers in workplaces are exposed to non-ionising radiation (ultraviolet and infrared). During work they use the necessary personal protective equipment (face shield, goggles, working clothes). Often on the site close to the mobile welding post there are also workers who do not wear the corresponding protective equipment. Ultraviolet radiation can be harmful to skin or eyes, causing erythraemia or conjunctivitis. Infrared radiation can damage the retina or cause cataracta, or damage to skin (Eglìte, 2000).

In Latvia the most frequent encountered occupational diseases in construction are:

- vibration-caused diseases (EUROSTAT code T752);

- spondylosis with radiculopathia (M472);

- carpal tunnel syndrome (G560);

- chronic obstructive lung diseases (J448);

- hearing nerve (n.vestibulocohlearis) diseases (H933);

- radiculopathia (541).

\section{MATERIALS AND METHODS}

The present study is based on the objective analysis of working environment measurements, and accidents at work in construction. Questionnaires were given to employers and employees. A total of 241 respondents from companies engaged in the construction sector were inquired, among altogether 2455 respondents from all branches of national economy $(9.8 \%)$.

Respondents were asked to respond according to a 10-point scale, where 1 means "does not satisfy at all" and "10" satisfies fully", to what extent occupational safety requirements are observed in the company (institution) they are working with, and their opinion on the structure of working environment risk factors in construction companies.

The study in the construction sector was conducted by the Hygiene and Occupational Diseases Laboratory of the Institute of Occupational and Environmental Health, Rīga Stradiňš University, during the period from 1998 till 2006. In 2006, 19 palm-wrist vibration measurements were made and entered in the database, other measurements made in 2006 that were carried out by the above laboratory are not included in the database and were not analysed). The laboratory carried out 956 measurements in the construction sector, of which the most often measured risk factors was noise $-22 \%(n=209)$, microclimate indexes (moisture $14 \%(\mathrm{n}=129)$, temperature $14 \%(\mathrm{n}=130)$, air motion velocity $14 \%(\mathrm{n}=129)$, and illumination $11 \%(\mathrm{n}=105)$. The lowest number of measurements was for chemicals (welding fumes, manganese, chromium, cement, wood dust, mineral fibres, and abrasive dust), hand-and-arm vibration measurements and identification of ergonomic working environment risk factors in workplaces/processes that are typical to construction. The number of measurements made in workplaces/processes since 2002 has increased significantly.

The results of measurements were compared with boundary values set according to the regulation for each risk factor in Latvia:

1. Occupational exposure limits for chemical substances are given in LVS 89:2004 "Professional exposure boundary values of chemical substances in working environment air" (Note 1 in Table 3);

2. Illumination exposure was based on ISO 8995:2002, exposure groups are formed on the basis of one of the lowest most often applicable recommended values for illumination in the work environment (Note 2 in Table 3);

3. For vibration the standardised eight-hour reference period daily exposure boundary value is defined in Regulation No. 284 of Cabinet of Ministers, "Labour Protection Requirements for the Protection of Employees from the Risk Caused by Vibration in the Work Environment" (became effective on 1 July 2005). In the period till 2005, ISO $2631-1$ and its Appendix ISO $2631-1.2$ were effective, where the whole-body vibration exposure boundary value was $0,5 \mathrm{~m} / \mathrm{s}^{2}$ and hand-and-arm vibration exposure $2 \mathrm{~m} / \mathrm{s}^{2}$ (Note 3 in Table 3 ); 
4. Microclimatic parameters (relative air humidity, air temperature and air motion velocity) for the exposure groups were divided taking into consideration the recommended values both in warm and cold periods for light- and medium-work difficulty categories (ГОСТ 12.1.005-88 “Система стандартов безопасности труда. Общие санитарно-гигиенические требования к воздуху рабочей зоны" (утв. 9 сентября 1988 г. N 3388; с изменениями от 20 июня 2000 г.; title in English „Осcupational safety standards system. General sanitary requirements for working zone air", which is similar to the regulations of the Ministry of Welfare of the Republic of Latvia "Hygiene regulations for working environment air", 1994), which corresponded to optimum air relative humidity in working environment for all difficulty categories (Note 4 in Table 3);

5. Measurements of noise are compared as $\mathrm{L}_{\mathrm{eq}}$ - uninterrupted equivalent $\mathrm{A}$-weighed sound pressure level, $\mathrm{dB}(\mathrm{A})$ (Note 5 in Table 3). Regulation No. 66 of Cabinet of Ministers of 4 February 2003, "Labour Protection Requirements for Protection of Employees from the Risk Caused by the Noise of the Work Environment", gives the lowest exposure value: $\left(\mathrm{L}_{\mathrm{EX}}, 8 \mathrm{st}\right)=80 \mathrm{~dB}(\mathrm{~A})$; highest exposure value: $\left(\mathrm{L}_{\mathrm{EX}}, 8 \mathrm{st}\right)=85 \mathrm{~dB}(\mathrm{~A})$ (the existing permissible exposure level also before 2003) and exposure boundary value $\left(\mathrm{L}_{\mathrm{EX}}, 8 \mathrm{st}\right)=87 \mathrm{~dB}(\mathrm{~A})$ (Note 6 in Table 3).

The questionnaire results were compared with the average statistical data in Latvia. Data were analysed using descriptive statistics. The $\chi^{2}$ (Chi square test) was used to evaluate significant $(P<0.05)$ differences between parameters. The rate of occupational diseases and accidents was calculated per 100000 employees. All data were analysed by the SPSS 16.0 programme and MS Office Vista Excel programme.

The accident analyses were conducted for the time period from 2002 till 2005, and health disorders and occupational diseases for 1999-2005.

\section{RESULTS}

Employers' questionnaire. In the questionnaire employers were asked to assess according to a 10-point scale, to what extent work environment in their company (institution) complies with the requirements of the Labour Protection Law. The average score in all sectors was 8.1, and employers in construction companies assessed the working environment slightly worse -7.8 points. $32.0 \%$ respondents had graded themselves with 9 and 10 points, $54.4 \%-7-8$ points, 9.8\% - 5-6 points, $3.8 \%-3-4$ points (no employer gave a score of 1 and 2 points). In 2000, among employers in Estonia, on a similar question, 32\% assessed themselves with 9 and 10 points, $32 \%$ with $7-8$ points, $35 \%$ - with 5-6 points, and 1\% with 3-4 points (Anonymous, 2000).
Regarding occupational safety requirements, employers scored their companies with 7.8 points, and $38.4 \%$ employers gave the highest evaluation ( 9 and 10 points).

According to employer opinion the structure of existing work environment risk factors in construction companies differs from that of over 11 work environment risk factors in Latvia. More frequently reported risk factors in construction were vibration caused by manual instruments, machine etc. vibration caused by transport, noise, high temperature, low temperature in rooms, draught, work outside in different weather conditions, chemical substances, work in awkward position, handling of heavy loads, monotonous movements, work with computer (at least two hours daily), work at height, work in explosive environment, work with different appliances, work with dangerous equipment, overtime work, work with complicated, fast-changing technologies, fast and important decision making, unchanging work pace, and shortage of time. Less common factors were ionising radiation, biological factors, shift work, and night work.

More often than the average in Latvia, employers invested financial resources in employee health examination (with insurance policies - $25.8 \%$ compared to $17.2 \%$ in Latvia, without policies - 50.2\% compared to $33.9 \%$ in Latvia). Mandatory health examination has not been carried out in nearly $25 \%$ construction companies, which is unsatisfactory considering the numerous work environment risk factors characteristic of construction, as well as work in special conditions (e.g. work at height, with dangerous equipment, etc.).

Regarding training of OSH specialists and trusted persons, the situation in construction is better than on the average in Latvia (53.0\% in construction, $32.0 \%$ on the average in Latvia). This is also true for training in first aid (37.9\% in construction, $27.3 \%$ on the average in Latvia), work clothes personal protective equipment $(85.1 \%$ in construction, $62.8 \%$ on the average in Latvia), and placement of safety signs $(65.2 \%$ in construction, $44.5 \%$ on the average in Latvia). Working environment risk factors have not been assessed in 36.8\% companies, which is less than in Latvia in general (altogether $54.8 \%$ ), made partly - 31.2\% companies (in Latvia 21.5\%), made fully - 32.0\% (in Latvia $26.0 \%)$.

According to the employer questionnaire, fewer employees in construction have submitted proposals for the improvement of working environment and labour legal relations than the average (20.1\% in construction, $26.1 \%$ in Latvia). Although the number of respondents from companies where they have received such proposals is relatively small, employees more often have suggested to provide social guarantees and improve work organisation. However, there has been less motivation to suggest improvement of public life conditions, premises, territory, rooms for smoking (6.8\% in construction, $28.4 \%$ on the average in Latvia).

Employee questionnaire. The average assessment of occupational safety requirements by employees in Latvian com- 
panies was 8.2 , and in construction companies slightly worse at 7.6. $35.6 \%$ respondents had assessed the construction company they are working with 9 and 10 points, $40.6 \%-7-8$ points, $14.4 \%-5-6$ points, $3.3 \%-3-4$ points; and $4.1 \%-1-2$ points.

According to the employee opinion, the structure of work environment risk factors in construction companies differs from that overall in Latvia, and risk factors are mentioned as more often than the average in Latvia (sometimes even 2-3 times more often) (see Table 1).

Less often than the average in Latvia, concrete employees working in the respective workplace $(32.9 \%$ in construction, $39.9 \%$ in Latvia) and the employee trusted person $(6.0 \%$ in construction, $9.5 \%$ in Latvia) participated in work environment risk assessment. $56.7 \%$ of construction companies where risk assessment has been made, have drawn up a preventive plan for work environment improvement and risk reduction, which is only slightly more often than the average in Latvia $50.1 \%$.

Regarding work environment risk factors in their workplaces (chemical, physical, ergonomic (awkward positions, lifting loads), psychosocial, injury risk factors, etc.), $58.7 \%$ respondents from the construction sector mentioned that they have received such information (on average in Latvia $55.6 \%$ ), $25.5 \%$ that have not received (in Latvia 17.8\%), $14.1 \%$ - this information is not necessary or not pertinent (in Latvia 24.3\%). Information on the influence of working environment risk factors on the health and necessary health examinations was received by $59.4 \%$ respondents from construction sector companies (in Latvia 60.6\%), have not received $-26.9 \%$ (on the average in Latvia19.3\%), not necessary / not pertinent - 12.8\% (in Latvia18.6\%). 76.5\% respondents from construction sector companies (in Latvia $53.2 \%$ ) were informed about personal protective equipment (e.g., earplugs, gloves, helmets, respirators, etc.) to be used, not informed - $11.1 \%$ (in Latvia 10.7\%), not necessary/ not pertinent $-11.6 \%$ (in Latvia $34.9 \%$ ).

Employees during the inquiry were asked questions whether their employer in the company has carried out different occupational safety related activities in the previous year (see Table 2).

Regarding personal protective equipment (e.g. earphones, gloves, helmets, respirators, etc.), $81.7 \%$ construction sector workers admitted that they need to wear these, which is nearly two times less than the average in Latvia (46.0\%). $83.6 \%$ respondents who must wear this gear mentioned that their employees have provided them with the required equipment fully, but $10.8 \%$ responded as partly (in Latvia provided fully $82.8 \%$, partly $-11.8 \%$ ). The situation in construction is similar as the average in Latvia also regarding wearing personal protective equipment (wear always in construction $80.5 \%$, on the average in Latvia $78.5 \%$, wear sometimes - in construction $18.4 \%$, in Latvia $18.2 \%)$.
Table 1

EMPLOYEE EXPOSURE TO WORK ENVIRONMENT RISK FACTORS IN THE CONSTRUCTION SECTOR AND ON AVERAGE IN LATVIA $^{1}$

\begin{tabular}{|c|c|c|}
\hline Work environment risk factors & $\begin{array}{l}\text { In the con- } \\
\text { struction } \\
\text { sector }(\%)\end{array}$ & $\begin{array}{c}\text { Average } \\
\text { in Latvia }(\%)\end{array}$ \\
\hline Handling of heavy loads & 75.6 & 52.4 \\
\hline $\begin{array}{l}\text { Work outside in different weather conditions } \\
\text { (in summer and winter) }\end{array}$ & 72.9 & 38.2 \\
\hline $\begin{array}{l}\text { Inhaling of volatile substances, smoke, dust or } \\
\text { dangerous chemical substances, absorbed } \\
\text { through skin }\end{array}$ & 68.7 & 40.3 \\
\hline Work at height & 68.5 & 17.4 \\
\hline Draught & 67.3 & 51.7 \\
\hline $\begin{array}{l}\text { Vibrations caused by manual instruments, ma- } \\
\text { chines, etc. }\end{array}$ & 66.1 & 24.0 \\
\hline $\begin{array}{l}\text { Noise is so loud that person must raise voice } \\
\text { to speak with others }\end{array}$ & 65.4 & 45.0 \\
\hline $\begin{array}{l}\text { Repetitive movements (e.g. of wrists or shoul- } \\
\text { ders) }\end{array}$ & 64.8 & 56.1 \\
\hline $\begin{array}{l}\text { Work in awkward position (e.g. sitting, stand- } \\
\text { ing) }\end{array}$ & 64.1 & 63.8 \\
\hline $\begin{array}{l}\text { Overtime work (works longer that set out in } \\
\text { labour contract) }\end{array}$ & 62.4 & 51.7 \\
\hline $\begin{array}{l}\text { Work with appliances (e.g. polishing ma- } \\
\text { chines, mills) }\end{array}$ & 58.2 & 22.3 \\
\hline Shortage of time & 51.1 & 51.1 \\
\hline $\begin{array}{l}\text { High temperature because of which employees } \\
\text { are sweating even when not working }\end{array}$ & 46.0 & 37.2 \\
\hline $\begin{array}{l}\text { Direct contact with people that are not em- } \\
\text { ployees of your workplace, such as buyers, } \\
\text { passengers, a.o. }\end{array}$ & 44.9 & 63.8 \\
\hline $\begin{array}{l}\text { Work with dangerous equipment (lifting de- } \\
\text { vices, boiler equipment, tanks, etc.) }\end{array}$ & 44.5 & 17.8 \\
\hline Low temperature in rooms & 41.6 & 31.1 \\
\hline $\begin{array}{l}\text { Work with fast changing technologies and } \\
\text { making fast and important decisions }\end{array}$ & 39.8 & 33.2 \\
\hline $\begin{array}{l}\text { Vibration caused by transport (e.g. tractors, } \\
\text { excavators, lorries) }\end{array}$ & 32.1 & 17.0 \\
\hline $\begin{array}{l}\text { Summary working time (different working } \\
\text { hours each day, may not altogether exceed } 56 \\
\text { hours per week) }\end{array}$ & 31.8 & 34.7 \\
\hline Absorbing chemical substances through skin & 29.8 & 21.4 \\
\hline $\begin{array}{l}\text { Unchanging working pace (e.g. employee } \\
\text { must work at a pace determined by work } \\
\text { equipment) }\end{array}$ & 28.4 & 25.0 \\
\hline $\begin{array}{l}\text { Work in explosive atmospheres (e.g. work } \\
\text { with gas, fine wood dust) }\end{array}$ & 25.9 & 12.0 \\
\hline Work with computer (at least 2 hours daily) & 18.0 & 36.4 \\
\hline $\begin{array}{l}\text { Chemical and biological substances causing } \\
\text { malignant tumours }\end{array}$ & 17.5 & 12.0 \\
\hline $\begin{array}{l}\text { Distanced work (work that is not performed in } \\
\text { the workplace but somewhere else, for exam- } \\
\text { ple, at home) }\end{array}$ & 17.2 & 18.8 \\
\hline $\begin{array}{l}\text { Night work (more than } 2 \text { hours during the pe- } \\
\text { riod from } 22.00-6.00)\end{array}$ & 15.4 & 23.1 \\
\hline Increased atmospheric pressure & 11.0 & 7.1 \\
\hline $\begin{array}{l}\text { Non-ionising radiation (ultraviolet, laser, in- } \\
\text { frared, a.o.) }\end{array}$ & 10.5 & 8.3 \\
\hline $\begin{array}{l}\text { Biological factors (e.g. tick-born encephalitis, } \\
\text { virus hepatitis germs, contact with blood, ani- } \\
\text { mals) }\end{array}$ & 9.7 & 19.6 \\
\hline Ionising radiation & 6.8 & 7.5 \\
\hline Shift work (work in shifts 8 hours every day) & 3.8 & 9.1 \\
\hline
\end{tabular}

${ }^{1}$ basis - all respondents, $\mathrm{n}=2455$ ). 
Table 2

EMPLOYEES (\%) HAVING MENTIONED IMPLEMENTATION OF OCCUPATIONAL SAFETY ACTIVITIES IN THE CONSTRUCTION SECTOR AND ON AVERAGE IN LATVIA ${ }^{1}$

\begin{tabular}{|c|c|c|}
\hline Occupational safety activity & $\begin{array}{c}\text { In construction } \\
\text { sector }(\%)\end{array}$ & $\begin{array}{l}\text { On the average } \\
\text { in Latvia }(\%)\end{array}$ \\
\hline $\begin{array}{l}\text { Employee instruction and training (e.g. on } \\
\text { fire safety and the like issues) }\end{array}$ & 62.8 & 69.0 \\
\hline $\begin{array}{l}\text { Working clothes and personal protective } \\
\text { equipment }\end{array}$ & 57.7 & 43.4 \\
\hline Purchase of first aid kit & 37.0 & 44.3 \\
\hline $\begin{array}{l}\text { Purchase and maintenance of fire protec- } \\
\text { tion means }\end{array}$ & 34.2 & 50.2 \\
\hline $\begin{array}{l}\text { Employee mandatory health examinations } \\
\text { (without insurance policy) }\end{array}$ & 33.3 & 37.8 \\
\hline $\begin{array}{l}\text { Placement of safety signs (e.g. attention } \\
\text { — electricity) }\end{array}$ & 32.9 & 34.8 \\
\hline $\begin{array}{l}\text { Improvement of work-related to public } \\
\text { life conditions (e.g. cloakrooms, shower } \\
\text { rooms, rooms) }\end{array}$ & 22.8 & 29.4 \\
\hline Training in rendering first aid & 19.8 & 26.2 \\
\hline $\begin{array}{l}\text { Health insurance policies (covering also } \\
\text { vaccination, mandatory health examina- } \\
\text { tions, a.o.) }\end{array}$ & 19.5 & 32.6 \\
\hline $\begin{array}{l}\text { Training of OSH specialists and trusted } \\
\text { persons }\end{array}$ & 12.5 & 13.6 \\
\hline $\begin{array}{l}\text { Improvement of working environment } \\
\text { (e.g. installation of ventilation) }\end{array}$ & 11.3 & 21.7 \\
\hline $\begin{array}{l}\text { Assessment of work environment risk fac- } \\
\text { tors }\end{array}$ & 10.9 & 13.2 \\
\hline Employee vaccination (without policy) & 8.8 & 20.8 \\
\hline $\begin{array}{l}\text { Sporting facilities for employees (without } \\
\text { policy) }\end{array}$ & 9.7 & 15.5 \\
\hline $\begin{array}{l}\text { Laboratory measurements of working en- } \\
\text { vironment }\end{array}$ & 2.9 & 5.3 \\
\hline
\end{tabular}

In the past three years, $56.3 \%$ respondents from the construction sector had undergone mandatory health examination, which is less than the average in Latvia (68.7\%).

Working environment conditions. A summary of work environment measurements expressed as mean values in the construction sector (F45) companies is presented in Table 3. Of 956 assessed workplaces/processes, in more than one half of cases $(\mathrm{n}=532 ; 55 \%)$ work environment risk factors exceeded boundary or recommended values $(P<0.05)$. Most often professional exposure boundary values or recommended values were exceeded for microclimate measurements (moisture 76\% $(\mathrm{n}=83)$, temperature $60 \%(\mathrm{n}=$ $75)$, air motion velocity $81 \%(\mathrm{n}=105)$, abrasive dust $72 \%$ $(\mathrm{n}=31)$, manganese $77 \%(\mathrm{n}=13)$, illumination $58 \%(\mathrm{n}=$ $61)$, welding aerosol $53 \%(\mathrm{n}=10)$, whole-body vibration $49 \%(\mathrm{n}=48)$, and noise $40 \%(\mathrm{n}=83)$ during the period from 1998 to 2005 .

Regarding chemical risk factors in the construction sector, welding aerosol, manganese concentration, abrasive dust, and cement dust most often exceeded the professional exposure boundary, reaching $64-100 \%$ of the measurements, but the sample size was too small to obtain an objective assessment (see Table 3).

Increased exposure occurred for all employees exposed to whole-body vibration, and there was an increased concentration of welding aerosol and manganese in the work environment. There was also commonly increased exposure to wood and abrasive dust for construction workers, inadequate (high or mostly lower) relative air humidity and air motion velocity, as well as high noise, which in 1999 exceeded the $85 \mathrm{~dB}(\mathrm{~A})$ level, but since 2003 exceeds the lowest noise exposure value: $\left(\mathrm{L}_{\mathrm{EX}}, 8 \mathrm{st}\right)=80 \mathrm{~dB}(\mathrm{~A})$ ) (see Table 3).

Accidents at work in construction. The accident analysis summarises data on the last four years. Table 4 shows the breakdown of accidents in construction sector per 100000 employees. In construction sector, the total number of accidents per 100000 employees is tended to decrease (216.6 in 2003, 196.8 in 2005), however, in the last four years there has been a high number of serious and fatal accidents with an increasing trend (70 in 2002, 93.9 in 2005). Between 2003 and 2005, the number of serious accidents has risen by 1.3 times (74.9 in 2003).

Regarding serious and fatal accidents the situation is much worse, and the construction sector occupies the second place, after wood felling, in the number of such accidents. The average number of serious accidents at work during the period from 2002 to 2005 in construction each year was on average 67 injured per 100000 employees (in wood felling sector - 107.6 serious accidents per 100000 employees). The number of serious accidents in the construction sector was 2.8 times higher than that in the country (24.1 injured per 100000 employees). The average number of fatal accidents at work during 2002 to 2005 was 15.9 injured annually per 100000 employees (in wood felling sector on the average 30.7 fatal accidents per 100000 employees). The number of fatal accidents in the construction sector was 3.6 times higher than the average number of fatal accidents in the country (4.4 dead per 100000 employees).

Occupational disease in construction sector. The total number of occupational diseases in construction in recent years has grown very little - from 33.8 cases per 100000 employees in 1999 to 38.9 cases in 2005. A faster growth was observed in 2002-2004, when the total number of occupational diseases increased from 40.4 to 59.1 cases (see Fig. 1). The increase of rate of occupational diseases was comparatively slower than in other sectors, and the total number of occupational diseases was comparatively low (e.g. in agriculture, forestry and hunting sectors it was 685.3 cases in 2005, transport sector - 199.1 cases per 100000 employees, but in the processing industry in the same year -150.2 cases).

\section{DISCUSSION}

The construction sector is associated with numerous risk factors, which can essentially endanger employee health 
AVERAGE MEASURED LEVELS OF WORK ENVIRONMENT RISK FACTORS IN 1998-2005 IN THE CONSTRUCTION SECTOR (F45)

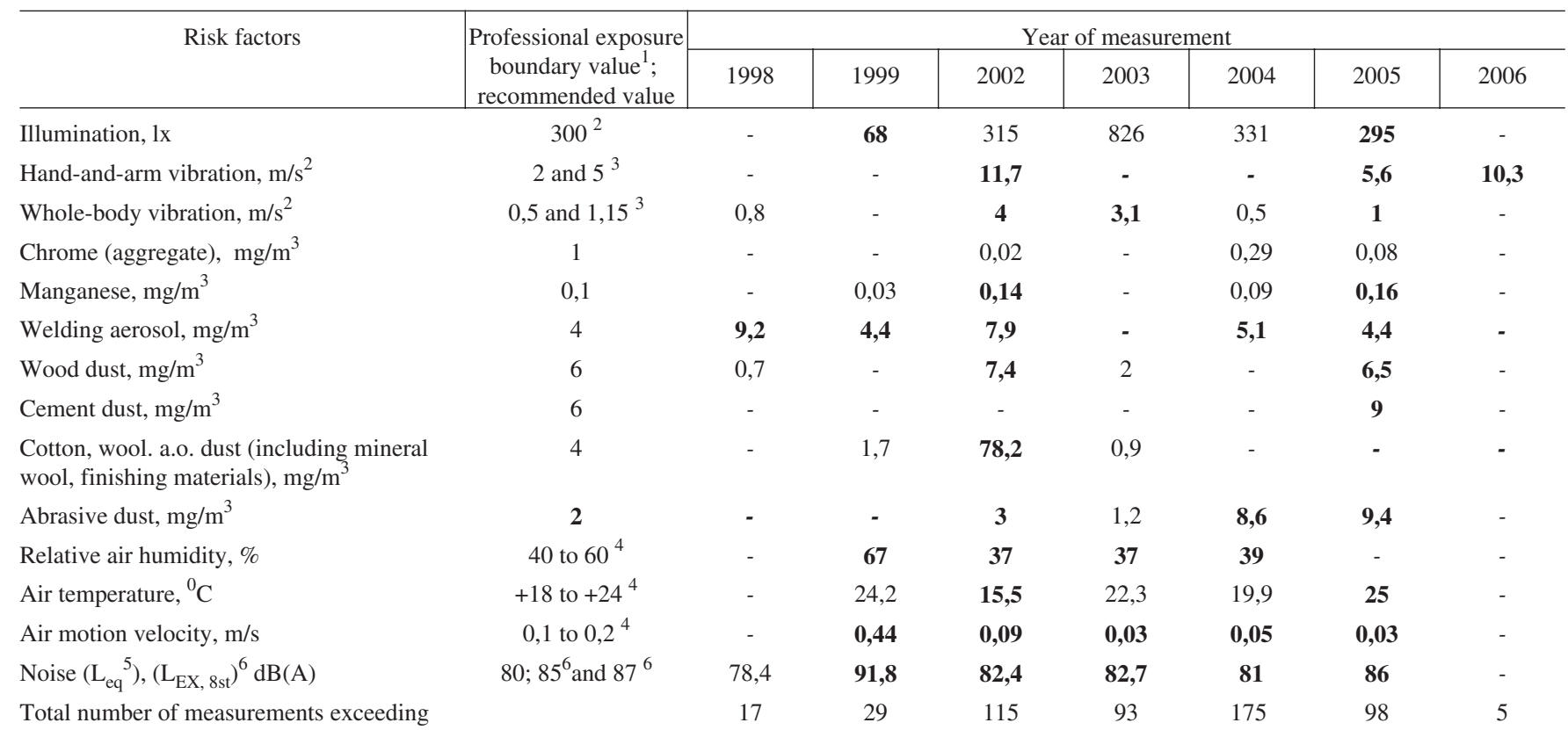

boundary values

Note: bold font identifies non-compliance to boundary values; ${ }^{1}-$ occupational exposure limits of chemical substances in work environment; ${ }^{2}-$ recommended values for illumination in work environment; ${ }^{3}$ - exposure boundary value of vibration; ${ }^{4}$ - recommended values of microclimatic parameters; 5 and 6 - exposure boundary values of noise.

Table 4 ACCIDENTS IN THE CONSTRUCTION SECTOR PER 100000 EMPLOYEES

\begin{tabular}{l|r|r|r|r}
\hline \multirow{2}{*}{$\begin{array}{c}\text { Accidents in construction } \\
\text { sector }\end{array}$} & \multicolumn{4}{|c}{ Years } \\
\cline { 2 - 5 } & \multicolumn{1}{|c}{2002} & 2003 & 2004 & \multicolumn{1}{c}{2005} \\
\hline Number of accidents & 216.6 & 220.2 & 224.4 & 196.8 \\
serious & 55.0 & 58.4 & 77.9 & 76.7 \\
fatal & 15.0 & 16.5 & 14.8 & 17.2
\end{tabular}

and safety, through causing accidents, occupational diseases and work-related diseases.

Although employers from the construction sector less often than the average in the country have mentioned that no company employee is exposed to harmful work environ- ment risk factors $(24.7 \%$ compared to $43.0 \%$ on the average in Latvia), considering the abundance of work environment risk factors and their presence in construction objects suggests that employers in construction companies are not completely aware about risk factors and their effect on worker health and safety. A slightly higher number of respondents than on the average in Latvia answered that all $100 \%$ workers are exposed to these risk factors $(19.7 \%$ compared to $16.0 \%$ on the average in Latvia). The opinion of employers on the extent to which the work environment in their company (institution) complies with the requirements of the Labour Protection Law was similar in Latvia and in Estonia (Anonymous, 2000).

Work environment risk factors have not been assessed in $36.8 \%$ companies and $50.4 \%$ employers in the construction

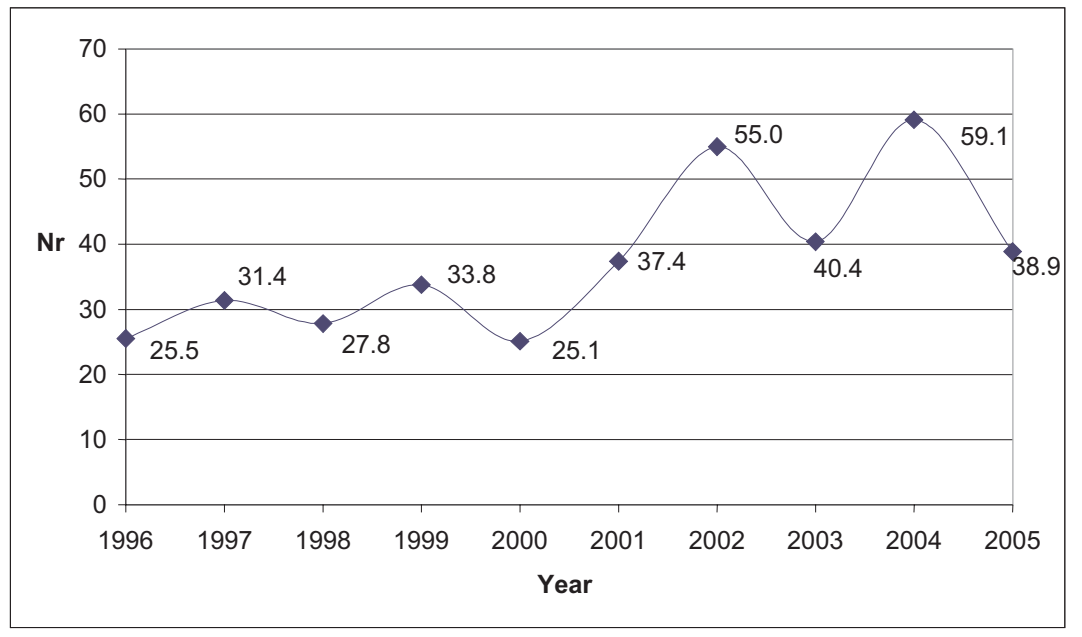

Fig. 1. Dynamics of the number of occupational diseases (per 100000 employees) in the construction sector (NACE code: F45). 
sector mentioned risk assessment as an occupational safety activity. Only $10.9 \%$ respondents considered risk assessment as an occupational safety activity. This means that even if the risk assessment has been made in a company, the employees have not been informed about it, and thus no valuable preventive activates are carried out for the reduction of accidents in workplaces.

According to the results of employer inquiry, twelve of the companies (or 12.8\%) during last three years have had accidents at work. More often employers of companies, which in the last three years have had accidents, represent the extraction industry and quarrying companies (17.5\%) followed by timber, wood and cork products, and furniture manufacturing companies $(14.5 \%)$.

The number of quantitative measurements made in the construction sector has increased significantly since 2002, which can be explained by the Labour Protection Law that came into effect in 2002 and other occupational safety related activates in construction.

Analyses of the laboratory measurement database shows that the whole-body vibration, noise, illumination, welding aerosol, manganese, wood and abrasive dust, relative air humidity and air motion velocity are the most significant risk factors in the construction sector, as the average values of these factors exceed professional exposure border values or allowable values set out in regulatory enactments. Also, $49 \%$ whole-body vibration measurements do not correspond $(P<0.05)$ to whole-body vibration norms, noise $40 \%$, illumination 58\%, welding aerosol 53\%, manganese $77 \%$, wood and abrasive dust $10 \%$, relative air humidity $76 \%$ and air motion velocity $81 \%$.

In the construction sector, relatively small attention is paid to the assessment of widely spread risk factors, such as cement dust and hand-and-arm vibration. Also, where building and dismantling works are carried out, during the work process no asbestos fibre measurements have been made (Thevendrom and Mawdeslay, 2004).

Some employers $(34.2 \%)$ admitted that accidents were caused by no observance of labour protection requirements by employees, $2 \%$ because of the drawbacks in work organization, 47\% - employees disregarded occupational safety requirements, in $16.8 \%$ cases the reasons were beyond the control of the requirements. After an accident, to prevent or reduce repeating of such accidents, the employer must carry out occupational safety activities $36.2 \%$ employers admitted that work organisation was changed, $26.8 \%$ replaced or improved equipment, in $60.4 \%$ cases employees were additionally instructed and trained, in $13.4 \%$ - additional personal protective equipment was provided, and $16.8 \%$ carried out other activities (more exact data on the construction sector are not available). Similar problems in injuries were observed in a case study in Turkey, where the highest risks were construction site equipment and motor vehicles (Gürcanli et al., 2008).
Employees during the inquiry were asked whether in their company (institution) in the last three years there had been any work-related accident. $20.0 \%$ of respondents from the construction sector stated that there have been such accidents. According to the employee opinion these most often were light accidents with one injured (47.5\%), much less often other accidents reported as light with several injured $(6.1 \%)$. Relatively much more often than the average in Latvia there were serious accidents with one injured $(35.8 \%)$ or several injured $(2.3 \%)$. In the construction sector it is relatively often mentioned that an employee/employees have died in accidents at work $(10.7 \%)$, which is the third highest after power, gas and water supply sector $(54.1 \%)$ and agriculture, forestry and hunting (12.7\%).

When analysing the most often encountered occupational diseases in the construction sector per 100000 employees, we see that the highest increase was for vibration-caused occupational diseases (from 12.5 cases in 2001 to 19.4 cases in 2005). The number of other occupational diseases actually has not grown. For example, the number of cases of spondylosis with radiculopathy in 2001 and in 2005 was similar (16.0 cases per 100000 employees), and the number of cases of carpal tunnel syndrome had even decreased (from 16.0 cases in 2001 to 9.2 in 2005). One explanation might be insufficient awareness of occupational diseases, or due to comparatively high illegal employment (no mandatory health examinations). It is also possible that in construction there are a comparatively high number of young and physically strong workers, and health disorders in young persons will become evident at later age when these persons are already working in other sector (Latze et al., 2000).

Although employers from construction companies have less often than on average in the country mentioned that no employee of their company is exposed to harmful working environment risk factors $(24.7 \%)$, considering the multiple risks at construction objects. This indicates that employers in construction companies are not sufficiently informed about the work environment risk factors and their influence on employee health and safety (Grausenth et al., 2006). More than one-third of employers have not ensured working environment risk assessment, which might be one of explanations why the number of accidents and occupational diseases in the sector is so high.

In view of the large number of working environment measurements exceeding the allowable professional exposure boundary values or recommended values, as well as the number of occupational accidents, the employers in most cases are unaware either of the requirements of regulatory enactments, or the high dangerousness of work environment risk factors (Anonīms, 2003).

In addition, the situation in construction regarding occupational safety has essentially worsened due to the shortage of workforce; as a result both employers and employees suffer from the shortage of time. Lack of information coupled with 
shortage of time is, possibly, one of the main causes of accidents (Grausenth et al., 2006).

According to the data of employee questionnaire a large number of accidents in construction are not registered in the State Labour Inspectorate (are concealed). In more than one-third of cases the employers have not introduced any occupational safety measures focused on prevention or reduction of future accident risk.

It is necessary to improve the supervision function over the observance of regulatory enactments in construction companies, since the research results point out a high accident risk and high accident concealing level, as well as a possibility that after the accident investigation in some cases nothing is being done to eliminate the accident causes.

The conclusions are:

1. Construction is characterised by an extremely wide range of tasks to be performed by incorporating many types of work, and frequent changes of the combination of the risk factors provoke combined effect on health. The most important risk factors in construction are physical, chemical and ergonomic risk factors.

2. A total of 956 measurements have been made in the construction sector from 1998 to 2006, of which in 532 cases $(55 \%)$ the assessed risk factors exceeded the professional exposure boundary values or allowable values set out in regulatory enactments.

3. The construction sector represents the highest number of fatal accidents in Latvia, yet regarding the total number of accidents it occupies only the fifth place (2005).

4. In construction, taking into consideration the sectorspecific risk factors and their consequences, the number of registered occupational disease is comparatively small.
5. The research results confirm a need to make amendments in regulatory enactments, establishing requirements for training of $\mathrm{OSH}$ coordinators in construction.

\section{REFERENCES}

Anonīms. (2003). Valsts Darba inspekcija. Atskaite par Latvijas - Dānijas sadarbības projekta realizāciju ES direktīvas 92/57/EEC par darba drošības un veselības aizsardzības prasībām pagaidu vai pārvietojamos būvlaukumos ieviešanā [Report on the realisation of the Latvian - Danish cooperation project on introducing the EU Directive 92/57/EEC on the implementation of minimum safety and health requirements at temporary or mobile construction sites]. http://www,osha,lv/research/docs/lat-danhtm.

Anonymous. (2000). Working Environment Survey (EMOR).

http://osh.sm.ee/research/emor_report.htm).

Eglīte, M. (2000). Darba medicīna [Occupational Medicine]. Rīga, 700 lpp. (59-135 lpp.) (in Latvian).

Gürcanli, G.E., Müngen, U., Akad, M. (2008). Construction equipment and motor vehicle related injuries and construction sites in Turkey. Ind. Health, 46(6), 375-388.

Grausenth, H.M., Lund, I., Wergeband, E. (2006). Risk factors for accidental injuries in the construction industry. Fdsskr. Nor. Lalglforen., 126(4), 453-456.

Latze, U., Kaimans, W., Stürmer, T., Steiner, M., Neth, A., Rehder, U. (2000). Chohort study of occupational risk factors of low back pain in construction workers. Occup. Environ. Med., 57, 28-34.

Roja, Ž., Kaḷis, V. (2001). Riska faktori un darbinieku arodveselība atsevišķās nozarēs: Būvniecība un būvmateriālu ražošana. Grām.: Darba vides riska faktori un strāājošo veselības aizsardzība [Risk Factors of Work Environment and Health Protection of Workers] (383.-395. 1pp.). Kal,kis, V., Roja, Ž. (red.). Rīga: Elpa. (in Latvian).

Sauni, K., Virtema, P., Pääkkönen, R., Toppila, E., Pyykkö, J., Vitti, J. (2010). Quality of life (EQ-5D) and hand-arm vibration syndrome. Int. Arch. Occup. Environ. Health., 83(2), 209-216.

Seidel, H. (2008). Selected health risks caused by long-term whole-body vibration. Amer. J. Industr. Med., 23(4), 589-604.

Thevendrom, V., Mawdeslay, M.J. (2004). Perception of human risk factors in construction projects: An exploratory study. Int. J. Project Manag., 22(2), 131-137.

Received 13 April 2010

\section{DARBA APSTĀKLII UN VESELĪBAS RISKI NODARBINĀTAJIEM BŪVNIECĪBĀ LATVIJĀ}

Pētījumā tiek apskatīta darba apstākḷu ietekme uz būvniecībā strādājošo veselību. Pētījuma mērḳis - novērtēt darba apstākḷus, identificēt riska faktorus darba vidē, analizēt arodsaslimšanu un negadījumus būvniecības nozarē. Būvniecības nozarē ir sastopami dažādi darba vides riska faktori, kas var radīt nozīmīgu kaitējumu nodarbināto veselībai un drošībai, izraisot nelaimes gadījumus darbā, arodslimības un ar darbu saistītās slimības. Pamatojoties uz Valsts Ieñēmumu dienesta datiem, Latvijā būvniecībā nodarbināto skaits katru gadu pieaug. Nelaimes gadījumu skaitam būvniecības nozarē uz 100000 nodarbināto tika konstatēta tendence samazināties, salīdzinot ar 2003 . un 2005. gadu, bet smago nelaimes gadījumu skaits bija pieaudzis 1,3 reizes. Pētījumā veiktajās aptaujās tika noskaidrots, ka par darba vides riska faktoriem būvniecības nozarē un to ietekmi uz nodarbināto veselību un drošību ir nepietiekami informēti gan darba devēji, gan nodarbinātie, kas nosaka nepieciešamību paplašināt darba drošības un veselības aizsardzības aktivitātes būvniecībā. 